Jurnal Penelitian Karet, 2014, 32 (1) : 10 - 20

Indonesian J. Nat. Rubb. Res. 2014, 32 (1): $10-20$

\title{
PERTUMBUHAN DAN PRODUKTIVITAS AWAL TANAMAN KARET BERBATANG BAWAH BANYAK
}

\author{
Growth and Initial Productivity of Rubber Plants with Many Rootstocks
}

Nurhawaty SIAGIAN dan Tumpal H. S. SIREGAR

Balai Penelitian Sungei Putih, Pusat Penelitian Karet

PO BOX 1415, Medan 20001

Email: nur_balit@yahoo.com

Diterima : 9 September 2013 / Direvisi : 15 Oktober 2013 / Disetujui : 12 November 2013

\begin{abstract}
Since 2005 the use of rubber planting materials with many rootstocks in order to shorten the immaturity period has been developed at the farm level. The models have continued growing and the planting materials are sold by trader in Regencies of Muara Enim, West Tanjung Jabung, Sarolangun, Madina, Taput, and Provincies of Bengkulu, Aceh, Jambi, as well as West Sumatra (Damas Raya and South Solok). Rubber planting material with many rootstocks logically will increase girth growth of rubber due to its more feeder roots for the absorption of water and nutrients. Technical information about the growth and production of this rubber planting material type needs to be disseminated in order to avoid mistakes in the future. The propagation of the rubber planting materials and its growth during in polybag was reported by Siagian in 2006 and in 2010 followed by the report of plant growth up to the age of 4 years in the field. This further research was conducted to evaluate its effects on the plant growth, percentage of tappable trees at the age of 4.5 years and tree production at three years of tapping. The experiment was conducted in experimental field of Sungei Putih, arranged in a factorial completely block design with three replications. Each experimental unit used 50 plants. The first factor tested was the number of rootstocks being grafted i.e. two (S2), three (S3), four (S4) and the control without grafting or only one rootstock (S1). The second factor were clones used i.e. PB 260 (K1) and IRR 118 (K2). Thus there were eight treatment combinations. Two-whorl polybag plants were used as planting materials. Field planting was done in May 2006. Variables observed were dry rubber production $(\mathrm{g} / \mathrm{t} / \mathrm{t})$, girth at 4.5 and 7.5 years old, percentage of tappable trees, bark thickness, number and diameter of latex vessels and nutrient leaf contents of $N, P, K$, $\mathrm{Mg}$ and $\mathrm{Ca}$ at the age of 7.5 years old. The results showed that the immaturity period of planting materials with many rootstocks (two, three or four) were almost equivalent to the immaturity period of the control plant i.e 4.5 years. The use of planting materials with many rootstocks (two, three or four)
\end{abstract}

for the purpose of shorthening immaturity period had not proved the previous assumption. Observations during three years of tapping showed that the average dry rubber production per tree per tapping on the plants with two, three and four rootstocks were not higher compared with the control.

Keywords: Hevea brasiliensis, roostocks, immaturity period, growth, dry rubber yield

\section{Abstrak}

Sejak tahun 2005 penggunaan bahan tanam karet berbatang bawah banyak dengan tujuan mempersingkat masa TBM telah berkembang di tingkat petani. Model pembibitan tersebut terus berkembang dan bibit diperjualbelikan oleh penangkar antara lain di Kabupaten Muara Enim, Tanjung Jabung Barat, Sarolangun, Madina, Taput, Provinsi Bengkulu, Aceh, Jambi, Sumatera Barat (Damas Raya dan Solok Selatan). Bahan tanam karet berbatang bawah banyak secara logika akan mendorong pertumbuhan batang karet karena mempunyai banyak akar untuk penyerapan air dan hara. Informasi teknis tentang perkembangan pertumbuhan dan produksi bibit karet berbatang bawah ganda perlu disebarluaskan agar tidak terjadi kekeliruan dikemudian hari. Teknik perbanyakan tanaman berbatang bawah banyak dan pertumbuhannya selama di polibeg telah dilaporkan secara lengkap oleh Siagian pada tahun 2006 dan pada tahun 2010 dilaporkan pertumbuhan tanaman sampai dengan umur 4 tahun di lapangan. Penelitian lanjutan ini dilakukan dengan tujuan untuk mengevaluasi pengaruhnya terhadap pertumbuhan, persentase pohon matang sadap pada umur 4,5 tahun dan produksi 3 tahun sadap tanaman karet di lapangan. Penelitian dilakukan di kebun percobaan Balai Penelitian Sungei Putih yang disusun menggunakan rancangan acak kelompok faktorial. Setiap unit percobaan menggunakan sebanyak 50 tanaman dan ulangan tiga kali. Faktor pertama yang diuji 
adalah jumlah batang bawah yang disambung/jumlah akar tunggang yaitu dua (S2), tiga (S3), empat (S4) dan kontrol tidak disambung atau hanya satu batang bawah/akar tunggang (S1). Faktor kedua adalah jenis klon yang diokulasikan yaitu klon PB 260 dan klon IRR 118. Dengan demikian terdapat sebanyak 8 kombinasi perlakuan. Penanaman di lapangan menggunakan bahan tanam polibeg dua payung, dilakukan pada akhir bulan Mei tahun 2006. Peubah yang diamati adalah produksi karet kering (gram per pohon per sadap), lilit batang pada umur 4,5 tahun dan 7,5 tahun, persentase tanaman yang memenuhi kriteria matang sadap, tebal kulit, jumlah dan diameter pembuluh lateks, kadar hara N, P, K, Mg dan Ca daun pada umur 7,5 tahun. Hasil penelitian menunjukkan bahwa masa TBM pada tanaman berbatang bawah dua, tiga dan empat hampir setara dengan masa TBM pada tanaman berbatang bawah satu (kontrol), yaitu 4,5 tahun. Penggunaan bahan tanam berbatang bawah banyak (dua, tiga, maupun empat) untuk tujuan mempersingkat masa TBM belum terbukti sebagaimana dianggap sebelumnya. Pengamatan selama 3 tahun sadap menunjukkan bahwa rataan produksi karet kering per pohon per sadap pada tanaman yang berbatang bawah dua, tiga dan empat tidak lebih tinggi dibandingkan dengan kontrol (berbatang bawah satu).

Kata kunci : Hevea brasiliensis, batang bawah, masa TBM, pertumbuhan, hasil karet kering

\section{PENDAHULUAN}

Ukuran keberhasilan TBM (Tanaman Belum Menghasilkan) secara teknis pada budidaya karet adalah jika digunakan bahan tanam prima dengan klon unggul, pertumbuhan lilit batang jagur (10-12 cm per tahun), tanaman seragam dengan koefisien keragaman lilit batang $(\mathrm{CV}) \leq 15 \%$ dan jumlah pohon per hektar tetap optimal ( \pm 550 pohon/ha). Jika faktor tersebut di atas tercapai dan dengan dukungan manajemen dan agroklimat yang baik, maka produktivitas awal (pada tahun sadap pertama) sebesar $\pm 1300 \mathrm{~kg} / \mathrm{ha}$ tidak sulit terealisasi. Sampai dengan saat ini, dengan menggunakan teknologi terkini masa TBM yang paling cepat tercapai umumnya adalah 4 tahun. Dalam agribisnis tanaman karet, mempercepat masa TBM sangat penting karena akan mempercepat perolehan produksi dan pengembalian modal. Hal ini sangat beralasan karena nilai kini jauh lebih penting dibandingkan dengan nilai nanti. Dalam rangka mempercepat masa TBM dan meningkatkan produktivitas selama masa TM (Tanaman Menghasilkan), perbaikan kultur teknik (termasuk pembibitan karet) pada masa TBM masih sangat diperlukan.

Agustan (2005) mengembangkan model pembibitan karet yang disebut dengan bibit "berbatang bawah ganda". Model pembibitan tersebut terus berkembang dan bibit diperjualbelikan oleh penangkar antara lain di Kabupaten Muara Enim, Kabupaten Tanjung Jabung Barat, Kabupaten Sarolangun, Provinsi Bengkulu, Provinsi Aceh, Provinsi Jambi, Kabupaten Madina, Kabupaten Tapanuli Utara, Provinsi Sumatera Barat (Damas Raya dan Solok Selatan). Bibit diproduksi dengan melakukan penanaman sebanyak 3 kecambah karet di polibeg. Setelah tinggi tanaman $\pm 20 \mathrm{~cm}$, ketiga batang bawah ditautkan dan setelah 3-4 minggu (batang sudah menyatu), dua batang dipotong dan disisakan satu batang yang terjagur. Selanjutnya 4-5 bulan kemudian, dilakukan okulasi dan tunas okulasi dipelihara sampai mencapai stadia dua payung daun dan selanjutnya dipindahkan ke lapangan.

Secara logika tanaman yang berakar tunggang banyak sebagaimana diuraikan sebelumnya akan mempunyai akar lateral yang banyak juga. Hasil penelitian terdahulu menunjukkan bahwa tanaman karet yang mempunyai akar lateral lebih banyak menunjukkan pertumbuhan yang lebih jagur (Manurung, 1984; Manurung et al., 1985). Pada klon RRIC 100, pertumbuhan tanaman yang akar tunggangnya bercabang adalah lebih besar dibandingkan dengan pertumbuhan tanaman yang akar tunggangnya tidak bercabang atau akar tunggang satu, sedang pada klon RRIM 712 tidak berbeda (Siagian et al., 1990). Akar tunggang yang bercabang menumbuhkan akar lateral yang lebih banyak dibandingkan dengan akar tunggang tidak bercabang (Manurung, 1984). Semakin luas permukaan akar hara/akar lateral, maka kemampuan tanaman mengambil hara dari dalam tanah semakin besar dan diharapkan pertumbuhan batang akan lebih jagur. sehingga masa TBM menjadi lebih singkat. Tanaman yang berbatang bawah ganda diharapkan berdiri kokoh dan relatif tahan terhadap serangan angin. Hal-hal tersebut diatas diharapkan terjadi pada tanaman yang menggunakan bibit "berbatang bawah ganda". 
Beberapa Dinas Perkebunan (Kabupaten Muara Enim dan Jambi) dan Dinas Kehutanan dan Perkebunan (Kabupaten Sarolangun dan Kuala Tungkal) tertarik untuk mengembangkan jenis tanaman berbatang bawah ganda ini. Balai Penelitian Sungei Putih dengan hasil penelitian ini akan memberikan informasi teknis tentang budidaya bibit "berbatang bawah ganda" agar tidak terjadi kekeliruan di kemudian hari.

Teknik perbanyakan tanaman berbatang bawah banyak dan bagaimana pertumbuhannya selama di polibeg telah dilaporkan secara lengkap oleh Siagian pada tahun 2006 dan pada tahun 2010 dilaporkan pertumbuhan tanaman sampai dengan umur 4 tahun di lapangan. Pengamatan pada penelitian tersebut terus dilanjutkan dengan tujuan untuk mengevaluasi pengaruh jumlah akar tunggang terhadap pertumbuhan, persentase pohon matang sadap pada umur 4,5 tahun dan produksi pada 3 tahun sadap pertama.

\section{BAHAN DAN METODE}

Penelitian dilakukan di kebun percobaan Balai Penelitian Sungei Putih, Pusat Penelitian Karet pada periode tahun 2010 hingga 2013. Lahan percobaan berada pada ketinggian 80 meter di atas permukaan laut. Hasil analisis fisika dan kimia tanah areal percobaan sebelum penanaman dilakukan di lapangan tertera pada Tabel 1 . Percobaan disusun menggunakan rancangan acak kelompok faktorial. Faktor pertama yang diuji adalah jumlah batang bawah yang disambung/jumlah akar tunggang yaitu dua (S2), tiga (S3), empat (S4) dan kontrol tidak disambung atau hanya satu batang bawah/akar tunggang (S1) sebagaimana biasa diterapkan. Faktor kedua adalah jenis klon yang diokulasikan yaitu klon PB 260 dan klon IRR 118. Dengan demikian terdapat sebanyak 8 kombinasi perlakuan. Setiap unit percobaan diulang tiga kali dan pada setiap unit percobaan diamati sebanyak 50 tanaman.

Teknik pengadaan bahan tanam berbatang bawah banyak secara rinci telah dilaporkan sebelumnya (Siagian, 2006; Siagian, 2010). Secara ringkas pengadaannya adalah sebagai berikut: kecambah dari klon GT 1 ditanam di polibeg. Jumlah kecambah yang ditanam per polibeg bervariasi sesuai dengan jumlah batang bawah pada perlakuan. Untuk perlakuan tanaman berbatang bawah dua, ditanam dua kecambah per polibeg. Untuk perlakuan tanaman berbatang bawah tiga, ditanam tiga kecambah per polibeg dan untuk perlakuan tanaman berbatang bawah empat, ditanam empat kecambah per polibeg. Sebagai kontrol ditanam satu kecambah per polibeg (satu batang bawah). Pada umur 1,5 bulan dilakukan penyambungan batang bawah. Dalam proses penyambungan, selebar masing-masing $1 / 3$ bagian lilit batang (dengan panjang 10-15 $\mathrm{cm}$ ) dikuliti, lalu disatukan dengan cara mengikat dengan tali plastik putih. Satu bulan kemudian, plastik sambungan dibuka dan sambungan berhasil jika batang bawah yang disambung sudah utuh menjadi satu. Sepuluh hari setelah plastik dibuka, dilakukan pemotongan terhadap batang bawah dan ditinggalkan hanya satu batang bawah yang terjagur. Okulasi terhadap batang bawah yang terjagur dilakukan pada umur 4 bulan. Dua jenis klon yang diokulasikan yaitu klon PB 260 dan klon IRR 118.

Hasil okulasi yang telah mencapai stadia dua payung daun, selanjutnya ditanam di lapangan dengan jarak tanam $6 \mathrm{x}$ $3 \mathrm{~m}$. Persiapan lahan dilakukan secara mekanis dan penanaman di lapangan dilakukan pada awal bulan Mei tahun 2006. Penanaman kacangan penutup tanah tidak dilakukan di dalam percobaan ini. Pemeliharaan tanaman selama di lapangan mengikuti anjuran Balai Penelitian Sungei Putih. Pemupukan tanaman hanya dilakukan sampai tanaman berumur 3 tahun di lapangan dengan dosis sebagaimana tertera pada Tabel 2 .

Peubah yang diamati adalah :

1. Lilit batang yang diamati pada ketinggian $1 \mathrm{~m}$ dari pertautan okulasi dan persentase tanaman yang memenuhi kriteria matang sadap pada umur 4,5 tahun setelah tanam di lapangan. Pohon yang memenuhi kriteria matang sadap adalah pohon yang telah mencapai lilit batang $45 \mathrm{~cm}$ diukur pada ketinggian $1 \mathrm{~m}$ dari pertautan okulasi.

2. Produksi karet kering (g/p/s). Pada tahun sadap pertama, penyadapan dilakukan 
Tabel 1. Sifat fisika dan kimia tanah areal percobaan di lapangan yang diamati sebelum penanaman

Table 1. Physical and chemical properties of field soil in trial area was observed before planting

\begin{tabular}{lcc}
\hline \multicolumn{1}{c}{ Sifat fisika dan kimia tanah } & Hasil & Klasifikasi \\
\multicolumn{1}{c}{ Physical and chemical properties of soil } & Results & Classification \\
\hline Tekstur & & - \\
Pasir (\%) & 44 & - \\
Debu (\%) & 16 & - \\
Liat (\%) & 43 & Masam \\
pH & 4,4 & Rendah \\
Karbon (\%) & 1,86 & Rendah \\
Nitrogen (\%) & 0,16 & - \\
C/N & 11,6 & Rendah \\
P-av Bray-2 (ppm) & 21 & Tinggi \\
K (me/100 g) & 0,64 & - \\
Na (me/100 g) & 0,09 & Sedang \\
Mg (me/100 g) & 0,32 & Sangat rendah \\
Ca (me/100 g) & 0,92 & Rendah \\
Kapasitas Tukar Kation (me/100 g) & 7,10 & \\
\hline
\end{tabular}

Penentuan klasifikasi hara tanah mengacu pada Adiwiganda et al(1992)

Classification of soil nutrients refer to Adiwiganda et al (1992)

Tabel 2. Dosis pupuk di areal percobaan pada umur 1 - 3 tahun

Table 2. Dosage of fertilizer in the trial area at the age of $1-3$ years old

\begin{tabular}{ccccc}
\hline \multirow{2}{*}{$\begin{array}{c}\text { Umur (th) } \\
\text { Age }(y r)\end{array}$} & Urea & TSP & KCl & Kieserit \\
\cline { 2 - 5 } & \multicolumn{3}{c}{$g / \mathrm{p} / \mathrm{s} / t$} \\
\hline 1 & 225 & 120 & 100 & 30 \\
2 & 250 & 175 & 200 & 75 \\
3 & 250 & 175 & 200 & 100 \\
\hline
\end{tabular}

dengan sistem sadap $1 / 2 \mathrm{~S} d / 3$. Pada tahun sadap kedua dan ketiga dengan $1 / 2 \mathrm{~S} \mathrm{~d} / 3 \mathrm{ET} 2,5 \% \mathrm{Ga} 9 / \mathrm{y}(\mathrm{m})$. Pengamatan produksi $(\mathrm{g} / \mathrm{p} / \mathrm{s})$ dilakukan terhadap 20 pohon sampel pada setiap unit percobaan, sebanyak enam hari sadap dalam sebulan. Buka sadap dilakukan pada akhir bulan September 2010.

3. Lilit batang dan tebal kulit murni pada umur 7,5 tahun diamati pada ketinggian $1 \mathrm{~m}$ dari pertautan okulasi.

4. Anatomi kulit meliputi jumlah dan diameter pembuluh lateks pada umur 7,5 tahun. Contoh kulit untuk analisis pembuluh lateks diambil pada ketinggian $1 \mathrm{~m}$ dari pertautan okulasi dan diamati dengan menggunakan metode Gomez et al (1972).

5. Kadar hara N, P, K, Mg dan Ca daun pada umur 7,5 tahun.

\section{HASIL DAN PEMBAHASAN}

\section{Lilit Batang, Tebal Kulit dan Tanaman yang Memenuhi Kriteria Matang Sadap}

Hasil analisis statistik menunjukkan bahwa perlakuan jumlah batang bawah, 
klon dan interaksinya masing-masing berpengaruh tidak nyata terhadap peubah lilit batang, homogenitas $(\mathrm{KK}=$ koefisien keragaman) dan persentase tanaman yang memenuhi kriteria matang sadap (Tabel 3 ).

Pada umur 4,5 tahun (Gambar 1), walaupun secara statistik perlakuan jumlah batang bawah berpengaruh tidak nyata terhadap lilit batang, tetapi terdapat fakta bahwa pada klon PB 260, lilit batang tanaman berbatang bawah dua mencapai $47,7 \mathrm{~cm}$, lebih besar dibandingkan dengan lilit batang tanaman berbatang bawah satu/kontrol $(46,2 \mathrm{~cm})$, berbatang bawah tiga $(45,7 \mathrm{~cm})$ dan berbatang bawah empat $(44,4 \mathrm{~cm})$. Pada klon IRR 118, lilit batang tanaman berbatang bawah satu (kontrol) adalah $46,5 \mathrm{~cm}$, setara dengan lilit batang tanaman berbatang bawah dua $(46,5 \mathrm{~cm})$,

Tabel 3. Rataan lilit batang, koefisien keragaman (KK) lilit batang dan persentase matang sadap pada umur 4,5 tahun setelah tanam di lapangan

Table 3. Mean of girth, girth coefficient of variability (CV) and percentage of tappable trees at 4.5 years after field planting

\begin{tabular}{|c|c|c|c|c|c|c|c|c|c|}
\hline \multirow[b]{2}{*}{$\begin{array}{c}\text { Jumlah } \\
\text { batang } \\
\text { bawah } \\
\text { Rootstock } \\
\text { number }\end{array}$} & \multicolumn{3}{|c|}{$\begin{array}{l}\text { Klon PB } 260 \\
\text { Clone PB } 260\end{array}$} & \multicolumn{3}{|c|}{$\begin{array}{l}\text { Klon IRR } 118 \\
\text { Clone IRR } 118\end{array}$} & \multicolumn{3}{|c|}{$\begin{array}{l}\text { Rataan } \\
\text { Mean }\end{array}$} \\
\hline & $\begin{array}{c}\text { Lilit } \\
\text { batang } \\
\text { Girth } \\
(\mathrm{cm})\end{array}$ & $\begin{array}{l}\mathrm{KK} \\
C V \\
(\%)\end{array}$ & $\begin{array}{l}\text { Matang } \\
\text { sadap } \\
\text { Tappable } \\
\text { tress } \\
(\%)\end{array}$ & $\begin{array}{c}\text { Lilit } \\
\text { batang } \\
\text { Girth } \\
(\mathrm{cm})\end{array}$ & $\begin{array}{l}\mathrm{KK} \\
C V \\
(\%)\end{array}$ & $\begin{array}{l}\text { Matang } \\
\text { sadap } \\
\text { Tappable } \\
\text { tress } \\
(\%)\end{array}$ & $\begin{array}{c}\text { Lilit } \\
\text { batang } \\
\text { Girth } \\
(\mathrm{cm})\end{array}$ & $\begin{array}{l}\mathrm{KK} \\
C V \\
(\%)\end{array}$ & $\begin{array}{c}\text { Matang } \\
\text { sadap } \\
\text { Tappable } \\
\text { trees } \\
(\%)\end{array}$ \\
\hline Satu/One & 46,2 & 8,8 & 72,2 & 46,5 & 9,1 & 76,9 & $46,4 a$ & $8,9 a$ & $74,6 \mathrm{a}$ \\
\hline Dua/Two & 47,7 & 6,5 & 92,1 & 46,5 & 7,9 & 79,4 & $47,1 \mathrm{a}$ & $7,2 \mathrm{a}$ & $85,7 a$ \\
\hline Tiga/Three & 45,7 & 7,0 & 79,4 & 47,1 & 8,2 & 77,8 & $46,4 a$ & $7,6 \mathrm{a}$ & $78,6 a$ \\
\hline Empat/Four & 44,4 & 6,9 & 60,3 & 47,1 & 7,9 & 78,6 & $45,8 \mathrm{a}$ & $7,4 a$ & $69,4 a$ \\
\hline Rataan/Mean & 46,0 & 7,3 & 76,0 & 46,8 & 8,3 & 78,2 & & & \\
\hline
\end{tabular}

Angka-angka yang diikuti oleh huruf yang sama pada kolom yang sama, berbeda tidak nyata pada $\mathrm{P}=0,05$.

Figures followed by the same letter, in the same column were not significantly different at $P=0.05$

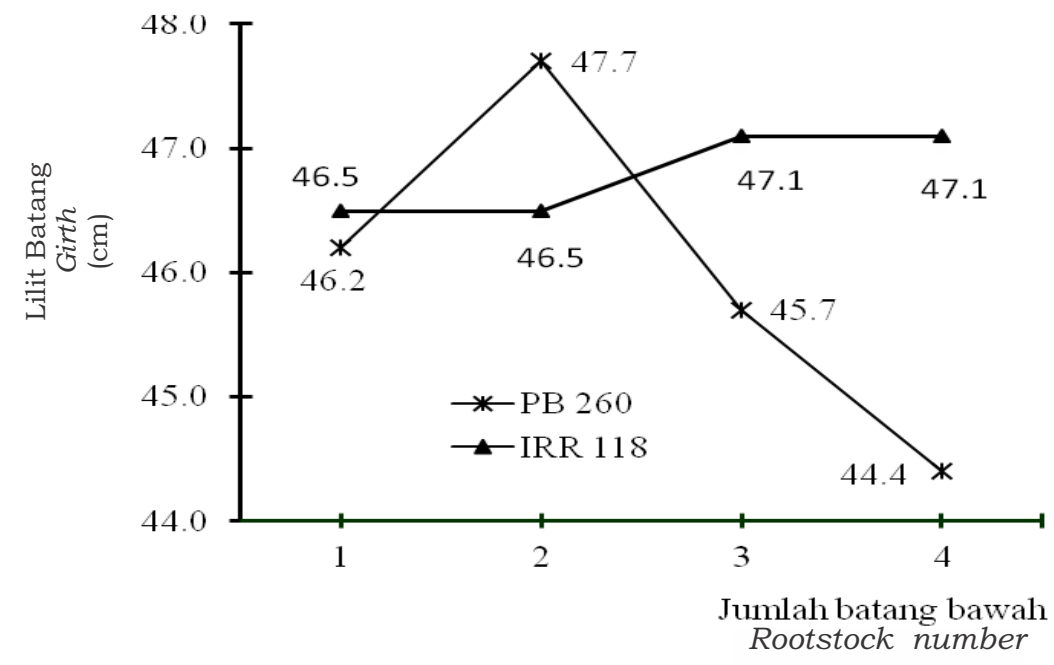

Gambar 1. Lilit batang pada umur 4,5 tahun

Figure 1. Girth at 4.5 years old 
sedangkan lilit batang tanaman berbatang bawah tiga setara dengan yang berbatang bawah empat $(47,1 \mathrm{~cm})$. Angka-angka di atas menunjukkan bahwa laju pertumbuhan lilit batang tanaman per tahun selama 4,5 tahun pengamatan untuk klon PB 260 adalah 10,3 cm pada tanaman berbatang bawah satu, 10,6 cm pada tanaman berbatang bawah dua, 10,2 cm pada tanaman berbatang bawah tiga dan 9,9 $\mathrm{cm}$ pada tanaman berbatang bawah empat. Laju pertumbuhan lilit batang tanaman per tahun selama 4,5 tahun pengamatan untuk klon IRR 118 adalah 10,3 cm pada tanaman berbatang bawah satu dan dua dan $10,5 \mathrm{~cm}$ pada tanaman berbatang bawah tiga dan empat. Dengan angka seperti di atas laju pertumbuhan tanaman masih tergolong normal, terutama pada kondisi tanah percobaan (kurang subur) sebagaimana diuraikan pada Tabel 1. Pada umur 4,5 tahun di lapangan, secara umum diketahui pertumbuhan klon IRR 118 hampir setara dengan pertumbuhan klon PB 260.

Tingkat homogenitas tanaman dapat dinilai dari besarnya angka koefisien keragaman (KK) lilit batang. Angka koefisien keragaman lilit batang pada umur 4,5 tahun dari berbagai perlakuan tertera pada Tabel 3 . Semakin rendah KK, maka semakin seragam tanaman tersebut. Pada tanaman karet, angka KK lilit batang kurang dari 10 termasuk sangat homogen dan jika angka tersebut berkisar 10-15\% termasuk cukup homogen. Tanaman karet yang seragam sangat diinginkan agar jumlah tanaman yang dapat disadap pada saat buka sadap adalah tinggi sehingga produktivitas pada awal sadap tinggi. Diketahui bahwa KK lilit batang tanaman berbatang bawah satu, dua, tiga dan empat berbeda tidak nyata satu sama lain yaitu masing-masing 8,9\%; $7,2 \% ; 7,6 \%$ dan $7,4 \%$ dengan kategori sangat homogen. Homogenitas tanaman sangat didukung oleh adanya seleksi dan pemilihan bahan tanam yang seragam pada saat penanaman di lapangan.

Dalam skala komersial, suatu areal Tanaman Belum Menghasilkan (TBM) dapat dimutasi menjadi areal Tanaman Menghasilkan (TM) jika minimal 60\% tanaman di areal tersebut telah mencapai kriteria matang sadap yaitu lilit batang 45 $\mathrm{cm}$ (diukur pada ketinggian $1 \mathrm{~m}$ dari pertautan okulasi). Biasanya buka sadap dilakukan pada satuan blok yang berukuran misalnya 15-25 ha. Pada penelitian ini persentase tanaman yang memenuhi kriteria matang sadap juga diamati, walaupun jumlah satuan unit percobaan hanya 50 tanaman. Persentase tanaman yang memenuhi kriteria matang sadap dari berbagai perlakuan tertera pada Tabel 3 dan Gambar 2. Hasil analisis statistik menunjukkan bahwa perlakuan jumlah batang bawah, klon dan interaksinya masing-masing berpengaruh tidak nyata terhadap persentase tanaman yang

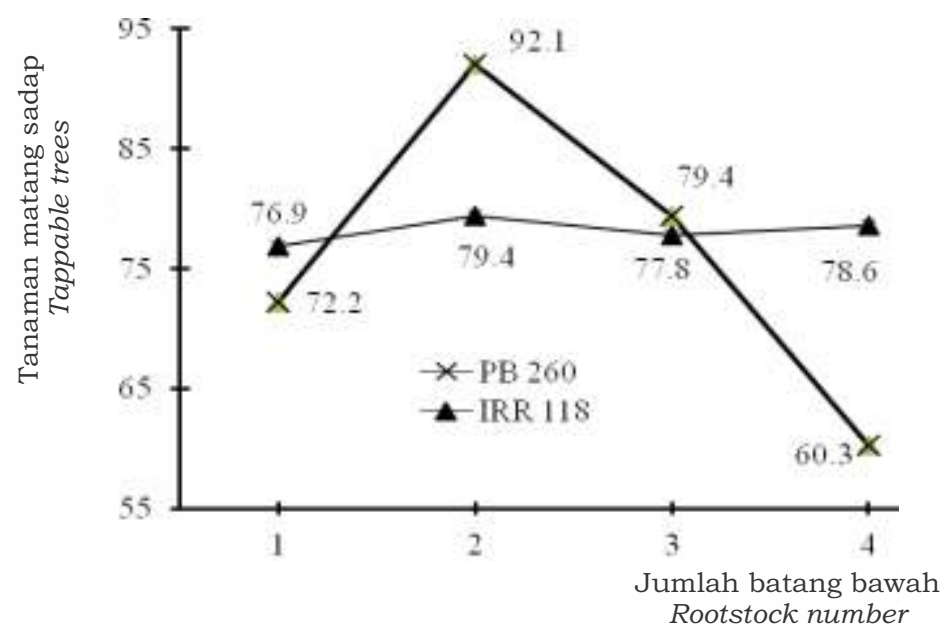

Gambar 2. Persentase pohon matang sadap pada umur 4,5 tahun

Figure 2. Percentage of tappable trees at 4.5 years old 
memenuhi kriteria matang sadap.

Pada umur 4,5 tahun (Gambar 2), walaupun secara statistik perlakuan jumlah batang bawah berpengaruh tidak nyata terhadap persentase matang sadap, terdapat fakta bahwa pada klon PB 260, persentase matang sadap pada tanaman berbatang bawah dua dan tiga masing-masing mencapai $92,1 \%$ dan $79,4 \%$ lebih besar dibandingkan dengan persentase matang sadap pada tanaman berbatang bawah satu/kontrol (72,2\%), sedangkan yang berbatang bawah empat hanya 60,3\%. Pada klon IRR 118, persentase matang sadap pada tanaman berbatang bawah satu (kontrol) 76,9\%, setara dengan angka pada tanaman berbatang bawah dua $(79,4 \%)$, berbatang bawah tiga $(77,8 \%)$ dan berbatang bawah empat $(78,6 \%)$. Angka-angka di atas menunjukkan bahwa penggunaan bahan tanam berbatang bawah banyak (dua, tiga, maupu empat) untuk tujuan mempersingkat masa TBM belum terbukti sebagaimana dianggap sebelumnya.

Rataan lilit batang dan tebal kulit pada umur 7,5 tahun dari berbagai perlakuan tertera pada Tabel 4. Dari hasil analisis statistik diketahui bahwa perlakuan jumlah batang bawah, jenis klon dan interaksinya berpengaruh tidak nyata terhadap peubah lilit batang dan tebal kulit. Rataan lilit batang pada umur 7,5 tahun, pada tanaman berbatang bawah satu, dua, tiga dan empat masing-masing adalah 59,1 $\mathrm{cm}, 58,2 \mathrm{~cm}, 55,3 \mathrm{~cm}$ dan 55,9 cm. Pada peubah tebal kulit, angka tersebut masingmasing adalah 7,2 mm, 7,3 mm, 7,0 mm dan 7,1 mm. Tebal kulit klon PB 260 dan klon IRR 118 masing-masing adalah 7,1 mm dan $7,2 \mathrm{~mm}$. Rataan lilit batang pada umur 7,5 tahun, pada klon PB 260 adalah $56,9 \mathrm{~cm}$ dan pada klon IRR 118 adalah $57,3 \mathrm{~cm}$.

\section{Jumlah dan Diameter Pembuluh Lateks pada Umur 7,5 tahun}

Rataan jumlah dan diameter pembuluh lateks pada umur 7,5 tahun dari berbagai perlakuan tertera pada Tabel 5 . Untuk peubah jumlah dan diameter pembuluh lateks, dari hasil analisis statistik juga diketahui bahwa perlakuan jumlah batang bawah, jenis klon dan interaksinya adalah berpengaruh tidak nyata. Rataan jumlah pembuluh lateks pada umur 7,5 tahun pada tanaman berbatang bawah satu (kontrol), dua, tiga dan empat masingmasing adalah 7,$5 ; 7,5 ; 7,4$ dan 7,8 pembuluh. Sementara rataan diameter pembuluh lateks masing-masing adalah 24,6; 24,0; 24,7 dan 24,2 mikron. Pada umur 7,5 tahun, tidak terdapat perbedaan yang nyata antara jumlah pembuluh lateks klon PB 260 dengan klon IRR 118 yaitu masing-masing 7,4 dan 7,7 pembuluh.

Tabel 4. Rataan lilit batang dan tebal kulit murni pada umur 7,5 tahun setelah tanam di lapangan

Table 4. Mean of girth and bark thickness at 7.5 years old after field planting

\begin{tabular}{|c|c|c|c|c|c|c|}
\hline \multirow{2}{*}{$\begin{array}{c}\text { Jumlah } \\
\text { batang bawah } \\
\text { Rootstocks } \\
\text { number }\end{array}$} & \multicolumn{2}{|c|}{$\begin{array}{l}\text { Klon PB } 260 \\
\text { Clone PB } 260\end{array}$} & \multicolumn{2}{|c|}{$\begin{array}{l}\text { Klon IRR } 118 \\
\text { Clone IRR } 118\end{array}$} & \multicolumn{2}{|c|}{$\begin{array}{c}\text { Rataan } \\
\text { Mean }\end{array}$} \\
\hline & $\begin{array}{c}\text { Lilit } \\
\text { batang } \\
\text { Girth } \\
\text { (cm) }\end{array}$ & $\begin{array}{l}\text { Tebal kulit } \\
\text { Bark } \\
\text { thickness } \\
\text { (mm) }\end{array}$ & $\begin{array}{c}\text { Lilit } \\
\text { batang } \\
\text { Girth } \\
\text { (cm) }\end{array}$ & $\begin{array}{c}\text { Tebal kulit } \\
\text { Bark } \\
\text { thickness } \\
\text { (mm) }\end{array}$ & $\begin{array}{l}\text { Lilit } \\
\text { batang } \\
\text { Girth } \\
\text { (cm) }\end{array}$ & $\begin{array}{c}\text { Tebal kulit } \\
\text { Bark } \\
\text { thickness } \\
\text { (mm) }\end{array}$ \\
\hline Satu/One & 60,0 & 7,2 & 58,2 & 7,1 & $59,1 \mathrm{a}$ & $7,2 \mathrm{a}$ \\
\hline Dua/Two & 59,0 & 7,3 & 57,4 & 7,4 & $58,2 \mathrm{a}$ & $7,3 a$ \\
\hline Tiga/Three & 53,5 & 6,9 & 57,1 & 7,2 & $55,3 a$ & $7,0 \mathrm{a}$ \\
\hline Empat/Four & 55,3 & 7,0 & 56,6 & 7,2 & $55,9 a$ & $7,1 \mathrm{a}$ \\
\hline Rataan/Mean & 56,9 & 7,1 & 57,3 & 7,2 & & \\
\hline
\end{tabular}

Angka-angka yang diikuti oleh huruf yang sama, pada kolom yang sama, berbeda tidak nyata pada $\mathrm{P}=0,05$ Figures followed by the same letters in the same column, were not significantly different at $P=0.05$ 
Tabel 5. Rataan jumlah dan diameter pembuluh lateks pada umur 7,5 tahun setelah tanam di lapangan

Table 5. Mean of number and diameter of latex vessels at 7.5 years after field planting

\begin{tabular}{|c|c|c|c|c|c|c|}
\hline \multirow[b]{2}{*}{$\begin{array}{l}\text { Jumlah } \\
\text { batang } \\
\text { bawah } \\
\text { Rootstock } \\
\text { number }\end{array}$} & \multicolumn{2}{|c|}{$\begin{array}{l}\text { Klon PB } 260 \\
\text { Clone PB } 260\end{array}$} & \multicolumn{2}{|c|}{$\begin{array}{l}\text { Klon IRR } 118 \\
\text { Clone IRR } 118 \\
\end{array}$} & \multicolumn{2}{|c|}{$\begin{array}{c}\text { Rataan } \\
\text { Mean }\end{array}$} \\
\hline & $\begin{array}{l}\text { Jumlah } \\
\text { pembuluh } \\
\text { lateks } \\
\text { Number of } \\
\text { latex } \\
\text { vessels }\end{array}$ & $\begin{array}{c}\text { Diameter } \\
\text { pembuluh } \\
\text { lateks } \\
\text { Diameter } \\
\text { of latex } \\
\text { vessels } \\
(\mu \mathrm{m})\end{array}$ & $\begin{array}{l}\text { Jumlah } \\
\text { pembuluh } \\
\text { lateks } \\
\text { Number of } \\
\text { latex } \\
\text { vessels }\end{array}$ & $\begin{array}{c}\text { Diameter } \\
\text { pembuluh } \\
\text { lateks } \\
\text { Diameter } \\
\text { of } \\
\text { latex } \\
\text { vessel } \\
(\mu \mathrm{m})\end{array}$ & $\begin{array}{l}\text { Jumlah } \\
\text { pembuluh } \\
\text { lateks } \\
\text { Number of } \\
\text { latex } \\
\text { vessels }\end{array}$ & $\begin{array}{c}\text { Diameter } \\
\text { pembuluh } \\
\text { lateks } \\
\text { Diameter } \\
\text { of latex } \\
\text { vessels } \\
(\mu \mathrm{m})\end{array}$ \\
\hline Satu/One & 7,6 & 24,7 & 7,5 & 24,5 & $7,5 a$ & $24,6 a$ \\
\hline Dua/Two & 7,2 & 22,7 & 7,8 & 25,2 & $7,5 a$ & $24,0 a$ \\
\hline Tiga/Three & 7,7 & 24,6 & 7,2 & 24,7 & $7,4 a$ & $24,7 \mathrm{a}$ \\
\hline Empat/Four & 7,3 & 23,1 & 8,3 & 25,4 & $7,8 \mathrm{a}$ & $24,2 \mathrm{a}$ \\
\hline Rataan/Mean & 7,4 & 23,8 & 7,7 & 25,0 & & \\
\hline
\end{tabular}

Angka-angka yang diikuti oleh huruf yang sama, pada kolom yang sama, berbeda tidak nyata pada $\mathrm{P}=0,05$

Figures followed by the same letters in the same column, were not significantly different at $P=0.05$

\section{Produksi Karet Kering (g/p/s)}

Hasil analisis statistik terhadap rataan produksi karet kering $(\mathrm{g} / \mathrm{p} / \mathrm{s})$ bulanan menunjukkan bahwa pada setiap periode pengamatan, tidak terdapat pengaruh interaksi antara jumlah batang bawah dengan jenis klon. Distribusi bulanan dari rataan produksi karet kering per pohon per sadap pada tahun sadap pertama, kedua dan ketiga dari keempat perlakuan jumlah batang bawah digambarkan masing-masing pada Gambar 3, 4 dan 5. Rataan produksi karet kering per pohon per sadap $(\mathrm{g} / \mathrm{p} / \mathrm{s})$ pada tahun sadap pertama, kedua dan ketiga tertera pada Tabel 6.

Dari Gambar 3 dan 4 diketahui bahwa pada tahun sadap pertama dan kedua, rataan produksi karet kering $(\mathrm{g} / \mathrm{p} / \mathrm{s})$ pada setiap bulan pengamatan pada perlakuan kontrol (batang bawah satu, S1) selalu lebih besar dibandingkan dengan rataan produksi karet kering $(\mathrm{g} / \mathrm{p} / \mathrm{s})$ pada perlakuan batang bawah dua (S2) dan batang bawah tiga (S3), tetapi berbeda tidak nyata jika dibandingkan dengan $\mathrm{g} / \mathrm{p} / \mathrm{s}$ pada perlakuan batang bawah dua (S2). Pada tahun sadap ketiga, walaupun secara statistik perlakuan jumlah batang bawah berpengaruh tidak nyata terhadap $\mathrm{g} / \mathrm{p} / \mathrm{s}$, nilainya pada perlakuan kontrol juga masih lebih tinggi dibandingkan dengan perlakuan lainnya (Tabel 6).

Di dalam penelitian ini dugaan sebelumnya yang diharapkan terjadi adalah bahwa setelah tanaman ditanam di lapangan, pertumbuhan akar lateral lebih bebas. Pertumbuhan akar lateral pada perlakuan batang bawah banyak diharapkan akan lebih tinggi dibandingkan dengan kontrol dan akhirnya diharapkan akan meningkatkan absorbsi air dan hara. Jika harapan itu terjadi maka logikanya adalah pertumbuhan dan produksi akan semakin meningkat. Untuk membuktikan hal tersebut, seyogyanya pertumbuhan akar lateral setelah ditanam di lapangan harus diamati, tetapi karena alasan teknis hal tersebut tidak dapat dilakukan. Dari angka rataan produksi karet kering $(\mathrm{g} / \mathrm{p} / \mathrm{s})$ pada tahun pertama, kedua dan ketiga diketahui bahwa dugaan tersebut tidak terbukti.

Diduga bahwa penyebab ketidaknyataan pengaruh perlakuan jumlah batang bawah terhadap pertumbuhan dan produksi karet kering (g/p/s) adalah terbatasnya area permukaan daun untuk kegiatan metabolisme, walaupun mungkin luas area akar hara meningkat pada perlakuan yang diuji, karena area permukaan daun terbatas (hanya satu 


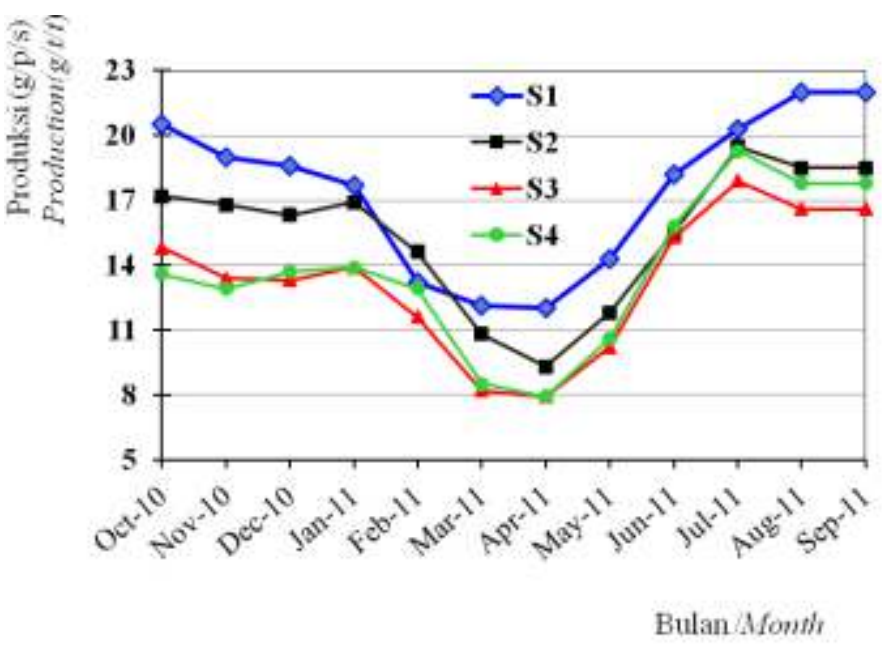

Gambar 3 . Produksi karet kering pada tahun sadap pertama Figure 3. Dry rubber production in the first tapping vear

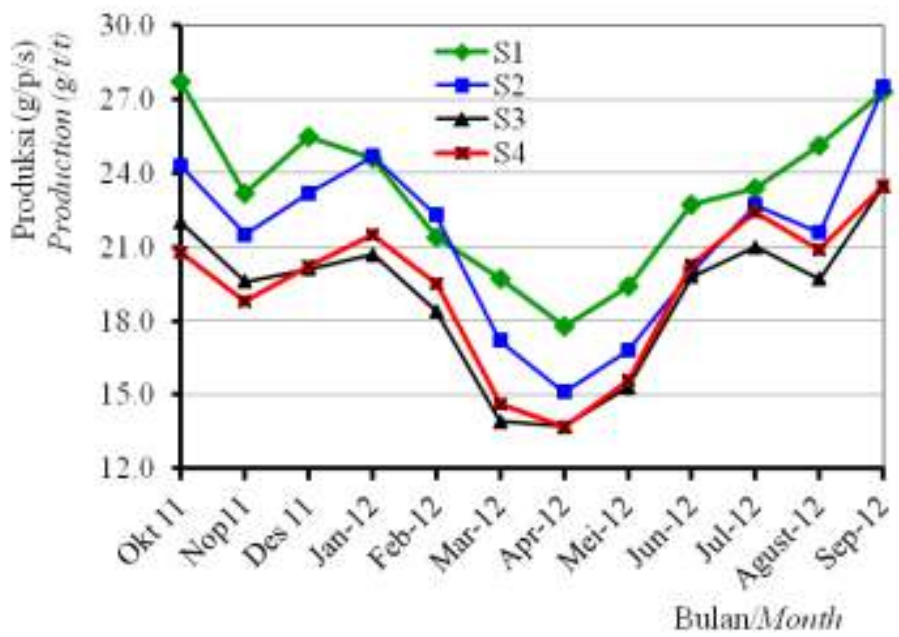

Gambar 4. Produksi karet kering pada tahun sadap kedua Figure 4 Drv rubber production in the second tapping vear

Tabel 6. Rataan produksi karet kering pada tahun sadap pertama, kedua dan ketiga Table 6. Mean of dry rubber production in the first, second and third years of tapping

\begin{tabular}{lccc}
\hline \multirow{2}{*}{$\begin{array}{c}\text { Jumlah batang bawah } \\
\text { Rootstock number }\end{array}$} & \multicolumn{3}{c}{$\begin{array}{c}\text { Produksi karet kering tahun sadap ke- } \\
(\mathrm{g} / \mathrm{p} / \mathrm{s})\end{array}$} \\
& \multicolumn{3}{c}{$\begin{array}{c}\text { Dry rubber production at tapping years } \\
(\mathrm{g} / \mathrm{t} / \mathrm{t})\end{array}$} \\
\cline { 2 - 4 } & 1 & 2 & 3 \\
\hline Satu/One & $17,5 \mathrm{a}$ & $23,2 \mathrm{a}$ & $33,3 \mathrm{a}$ \\
Dua/Two & $15,5 \mathrm{ab}$ & $21,4 \mathrm{ab}$ & $30,4 \mathrm{a}$ \\
Tiga/Three & $13,3 \mathrm{~b}$ & $19,0 \mathrm{~b}$ & $30,3 \mathrm{a}$ \\
Empat/Four & $13,7 \mathrm{~b}$ & $19,3 \mathrm{~b}$ & $29,6 \mathrm{a}$ \\
\hline
\end{tabular}

Angka-angka yang diikuti oleh huruf yang sama pada kolom yang sama, berbeda tidak nyata pada $\mathrm{P}=0,05$ Figures followed by the same letter in the same column, were not significantly different at $P=0.05$ 
batang atas pada masing-masing perlakuan), maka pembatasnya terdapat pada batang atas (source). Kemungkinan penyebab lainnya adalah bahwa pertautan antara batang bawah yang disambungkan kurang sempurna menyatu, sehingga transportasi air dan hara dari akar ke bagian tajuk tanaman atau sebaliknya transportasi hasil assimilat dari tajuk ke bagian bawah/akar kurang lancar. Jika hal ini terjadi maka rataan produksi karet kering per pohon sebagaimana terdapat pada hasil penelitian ini akan terjadi. Tentunya dugaan tersebut masih memerlukan pembuktian.
Kadar hara daun pada umur 7,5 tahun dari berbagai perlakuan tertera pada Tabel 7. Pada klon PB 260, kadar hara N daun dari ke-4 perlakuan yang diuji, secara umum berbeda tidak nyata satu sama lain dan berada pada score - 1 (di bawah optimum) menurut kriteria HBO (Hara Berimbang Optimum) yang dikemukakan oleh Adiwiganda et al (1992). Kadar masingmasing hara $\mathrm{P}, \mathrm{K}$ dan $\mathrm{Mg}$ daun dari klon $\mathrm{PB}$ 260, juga menunjukkan perbedaan yang tidak nyata antar perlakuan yang diuji, dan masing-masing berada di bawah optimum dengan score -1 untuk $\mathrm{P},-4$ untuk $\mathrm{K}$ dan +5 untuk Mg.

Tabel 7. Persentase kadar hara daun pada umur 7,5 tahun setelah tanam di lapangan

Table 7. Percentage of leaf nutrient content at 7.5 years after field planting

\begin{tabular}{|c|c|c|c|c|c|c|c|c|c|c|c|c|c|c|c|}
\hline \multirow{3}{*}{$\begin{array}{c}\text { Jumlah } \\
\text { batang bawah } \\
\text { Rootstock } \\
\text { number }\end{array}$} & \multicolumn{15}{|c|}{$\begin{array}{c}\text { Kadar hara daun } \\
\text { Leaf nutrient content } \\
(\%)\end{array}$} \\
\hline & \multicolumn{5}{|c|}{$\begin{array}{l}\text { Klon PB } 260 \\
\text { Clone PB } 260\end{array}$} & \multicolumn{5}{|c|}{$\begin{array}{l}\text { Klon IRR } 118 \\
\text { Clone IRR } 118 \\
\end{array}$} & \multicolumn{5}{|c|}{$\begin{array}{c}\text { Rataan } \\
\text { Mean }\end{array}$} \\
\hline & $\mathrm{N}$ & $\mathrm{P}$ & $\mathrm{K}$ & $\mathrm{Mg}$ & $\mathrm{Ca}$ & $\mathrm{N}$ & $\mathrm{P}$ & $\mathrm{K}$ & $\mathrm{Mg}$ & $\mathrm{Ca}$ & $\mathrm{N}$ & $\mathrm{P}$ & $\mathrm{K}$ & $\mathrm{Mg}$ & $\mathrm{Ca}$ \\
\hline Satu/One & 3,13 & 0,20 & 0,96 & 0,26 & 0,79 & 3,27 & 0,20 & 0,94 & 0,27 & 0,83 & 3,20 & 0,20 & 0,95 & 0,27 & 0,81 \\
\hline Dua/Two & 3,29 & 0,21 & 0,98 & 0,29 & 0,87 & 3,36 & 0,21 & 0,96 & 0,28 & 0,87 & 3,33 & 0,21 & 0,97 & 0,29 & 0,87 \\
\hline Tiga/Three & 3,22 & 0,23 & 0,96 & 0,26 & 0,8 & 3,36 & 0,18 & 0,98 & 0,28 & 0,85 & 3,29 & 0,21 & 0,97 & 0,27 & 0,83 \\
\hline Empat/Four & 3,10 & 0,19 & 0,94 & 0,25 & 0,8 & 3,47 & 0,21 & 0,94 & 0,29 & 0,89 & 3,29 & 0,20 & 0,94 & 0,27 & 0,85 \\
\hline Rataan/Mean & 3,19 & 0,21 & 0,96 & 0,27 & 0,82 & 3,37 & 0,20 & 0,96 & 0,28 & 0,86 & & & & & \\
\hline
\end{tabular}

Pada klon IRR 118, juga terjadi hal yang sama yaitu tidak terdapat perbedaan yang nyata antara kadar hara daun dari ke-4 perlakuan yang diuji. Umumnya unsur $\mathrm{N}$ masih berada pada kisaran optimum (score 0), unsur P dengan Score-3 sampai -2, unsur $\mathrm{K}$ dengan score -4 dan unsur $\mathrm{Mg}$ di atas optimum dengan score +5 . Diduga juga bahwa ketidaknyataan pertumbuhan secara signifikan diantara berbagai perlakuan yang diuji adalah salah satu akibat terbatasnya unsur hara yang tersedia di dalam tanah. KTK tanah yang rendah sebagaimana terdapat pada percobaan ini (Tabel 1) mengindikasikan rendahnya kemampuan tanah untuk mengikat unsur hara. Rendahnya kandungan bahan organik tanah merupakan salah satu penyebab rendahnya KTK tanah. Bahan organik menghasilkan humus (koloid organik) yang mempunyai permukaan yang dapat menahan unsur hara dan air sehingga kemampuan tanah untuk mengikat unsur hara meningkat. Di dalam penelitian ini tidak dilakukan penanaman kacangan penutup tanah dan pemupukan tanaman hanya dilakukan sampai umur 3 tahun dengan dosis sebagaimana tertera pada Tabel 2 .

\section{KESIMPULAN}

Dari hasil penelitian ini dapat ditarik kesimpulan sebagai berikut:

$\square$ Pada umur 4,5 tahun, perlakuan jumlah batang bawah, klon dan interaksinya berpengaruh tidak nyata terhadap peubah lilit batang dan persentase tanaman yang memenuhi kriteria matang sadap.

Penggunaan bahan tanam berbatang bawah banyak (dua, tiga maupun empat) untuk tujuan mempersingkat masa TBM belum terbukti sebagaimana dianggap sebelumnya. Masa TBM pada tanaman 
berbatang bawah dua, tiga dan empat hampir setara dengan masa TBM pada tanaman berbatang bawah satu (kontrol) yaitu 4,5 tahun.

- Pada tahun sadap pertama dan kedua, rataan produksi karet kering $(\mathrm{g} / \mathrm{p} / \mathrm{s})$ pada setiap bulan pengamatan pada perlakuan kontrol (batang bawah hanya satu) selalu lebih besar dibandingkan dengan rataan produksi karet kering $(\mathrm{g} / \mathrm{p} / \mathrm{s})$ pada perlakuan batang bawah 2 dan batang bawah 4, tetapi berbeda tidak nyata jika dibandingkan pada perlakuan batang bawah dua. Pada tahun sadap ketiga, walaupun secara statistik perlakuan jumlah batang bawah berpengaruh tidak nyata terhadap $\mathrm{g} / \mathrm{p} / \mathrm{s}$, nilainya pada perlakuan kontrol terlihat masih lebih tinggi dibandingkan dengan perlakuan lainnya. Produktivitas per pohon $(\mathrm{g} / \mathrm{p} / \mathrm{s})$ belum terbukti lebih tinggi pada tanaman yang menggunakan batang bawah banyak.

\section{DAFTAR PUSTAKA}

Adiwiganda, Y.T., A. Hardjono, A. Manurung, U.T.B. Sihotang, Darmandono, Sudiharto, D. H. Goenadi dan H. Sihombing. 1992. Pedoman Penyusunan Rekomendasi Pemupukan Karet. Asosiasi Penelitian dan Pengembangan Perkebunan Indonesia, Bogor.

Agustan. 2005. Tanaman Karet Berbatang Bawah Ganda. Agustan. Singkut Sarolangun, Jambi.
Gomez, J., R. Narayanan, and K. T. Chen. 1972. Some Structural Factors Affecting the Productivity of Hevea Brasiliensis : Quantitative Determination of Laticiferous Tissue. J.Rubb.Res.Inst.Malaysia 23(3): 193203.

Manurung, A., H. Sarban dan H. Munthe. 1985. Pengaruh Pemotongan Radikula terhadap Jumlah Cabang Akar Tunggang pada Bibit Karet. Kultura 18(111-112): 30-35.

Manurung, A. 1984. Pengaruh Perlakuan Kulit dan Bahan Perangsang Terhadap Pertumbuhan Akar Sisi Pada Bagian Tengah Akar Tunggang Bibit Karet. Kultura 17(109): 8-18.

Siagian, N., A. Manurung dan Sunarwidi. 1990. Penggunaan Stum Okulasi yang Akar Tunggangnya Bercabang Sebagai Bahan Tanam Polibeg Dalam Media Gambut. Prosiding Konferensi Nasional Karet 1990. Palembang, 18-20 September. Pusat Penelitian Karet.:

Siagian, N. 2006. Penggunaan Bahan Tanam Karet Three In One untuk Mempersingkat Masa Tanaman Belum Menghasilkan. Jurnal Penelitian Karet 24 (2): 101-113.

Siagian, N. 2010. Peluang Mempersingkat Masa Belum Menghasilkan pada Tanaman Karet Melalui Penggunaan Bahan Tanam Berbatang Bawah Banyak. Jurnal Penelitian Karet 28 (1): 11-25. 